\title{
GEOQUÍMICA DAS ROCHAS GRANULÍTICAS DO COMPLEXO JUIZ DE FORA, SEGMENTO CENTRAL DA FAIXA RIBEIRA
}

\author{
B.P.Duarte ${ }^{1}$, M.C.H.Figueiredo (in memorian) ${ }^{2}$, M.C.Campos Neto $^{2}$, M.Heilbron ${ }^{1}$
}

No segmento central da Faixa Ribeira, o Complexo Juiz de Fora (CJF) é constituído de ortognaisses, migmatitos e metabasitos na fácies granulito e lentes subordinadas de ortognaisses cinzentos, na fácies anfibolito. $\mathbf{O}$ CJF ocorre como escamas tectônicas interdigitadas com metassedimentos de idade pós-1,8 $\mathrm{Ga}$. com paragêneses típicas da fácies anfibolito e paragnaisses migmatíticos a ortopiroxênio de posição estratigráfica indeterminada. Estudos geocronológicos (Cordani et al., 1973) indicam que as rochas do CJF foram geradas e granulitizadas no Evento Transamazônico, ca. 2,2-1,8 Ga, e retrometamorfizadas durante a Orogênese Brasiliana (600 - $450 \mathrm{Ma})$.

Com base em dados de campo e análise petrográfica, 21 amostras do CJF foram selecionadas para o estudo litogeoquímico. Estes dados levaram à identificação de 4 séries magmáticas distintas: toleiítica; calcioalcalina de médio a alto $\mathrm{K}$; calcioalcalina de médio $\mathrm{K}$; e calcioalcalina de alto $\mathrm{K}$.

A série toleiítica (ST) é constituída de litotipos de composição basáltica, refletindo restrita variação no conteúdo de silica. Estas rochas (meta-noritos) ocorrem sob a forma de bandas e boudins inclusos nas rochas das séries calcioalcalinas. Com base nas abundâncias de elementos maiores e traços, dois grupos distintos de toleiítos foram identificados: um toleiíto de alto $\mathrm{Mg}(\mathrm{AMgT})$, caracterizado por teores mais altos de $\mathrm{MgO}$ e $\mathrm{CaO}$ e mais baixos de $\mathrm{FeO}, \mathrm{Sr}$, elementos de alto potencial iônico (HFSE) e elementos Terras Raras (ETR) em relação ao toleiíto de baixo $\mathrm{Mg}$ (BMgT). Os padrões de ETR normalizados para condrito mostrados pelos $\mathrm{AMgT}$ são horizontais, enquanto que aqueles dos $\mathrm{BMgT}$ são ligeiramente fracionados e apresentam anomalias negativas em Eu. Aranhogramas normalizados para NMORB indicam que ambos os tipos de toleiíto são caracterizados por um enriquecimento seletivo nos elementos de baixo potencial iônico (LFSE). Considerando o conteúdo em HFSE, os BMgT mostram abundâncias semelhantes às de $\mathrm{N}-\mathrm{MORB}$, enquanto que os $\mathrm{AMgT}$ são fortemente empobrecidos. As abundâncias em elementos traços sugerem uma fonte mantélica empobrecida para a ST e as altas razões LFSE/HFSE apontam para a participação de um componente de subducção (metassomatismo da fonte mantélica) e, possivelmente, de um componente de contaminação crustal.

A série calcioalcalina de médio a alto $\mathrm{K}$ (SCMAK) inclui rochas de composição diorítica a granodiorítica, enquanto que a de médio K (SCMK) é constituída de rochas mais ácidas (granodioritos e granitos). A primeira mostra enriquecimento relativo em $\mathrm{Al}_{2} \mathrm{O}_{3}, \mathrm{~K}_{2} \mathrm{O}, \mathrm{Ba}, \mathrm{Rb}, \mathrm{Sr}, \mathrm{Th}, \mathrm{Zr}$ e ETR leves. Por outro lado, a SCMK tem maiores teores de elementos compatíveis ( $\mathrm{FeO}, \mathrm{MnO}, \mathrm{MgO}, \mathrm{CaO}, \mathrm{Ni}$ e $\mathrm{Cr}$ ) e da maioria dos $\mathrm{HFSE}$. Padrões de ETR normalizados para condrito da SCMAK são fortemente fracionados nos ETR leves e ligeira

\footnotetext{
${ }^{1}$ DGRG, Faculdade de Geologia, Universidade do Estado do Rio de Janeiro.

${ }^{2}$ DGG, Instituto de Geociências, Universidade de São Paulo.
} 
a moderadamente fracionados nos ETR pesados. Anomalias negativas de Eu indicam fracionamento de plagioclásio na fonte. A SCMK mostra padrões mais fracionados nos ETR leves do que nos pesados. As diferenças mais marcantes existentes entre estes dois padrões são a forte anomalia negativa em Sm e a moderada anomalia positiva em Eu, apresentadas pela SCMK.

A série calcioalcalina de alto $\mathrm{K}$ (SCAK) ocorre como leucossomas graníticos (s.s.) em ortogranulitos migmatíticos. Os padrões de ETR normalizados para condrito são fortemente fracionados, mesmo quando comparados aos das demais séries calcioalcalinas. Anomalias em Eu ou Sm não foram observadas.

Em diagramas discriminantes para ambientes tectônicos, a ST coincide com toleiítos de baixo K, ora de arcos de ilha, ora de fundo oceânico (MORB ou bacias de retro-arco). A ausência de rochas ultramáficas e metassedimentares no CJF e as características geoquímicas discutidas sugerem que a ST foi gerada em um ambiente tectônico compressivo, provavelmente na raiz de um arco de ilha imaturo. A especulação sobre o envolvimento de um componente de contaminação crustal na gênese da ST é baseada na existência de rochas Arqueanas na Faixa Ribeira.

As SCMAK e SCMK, quando plotadas em diagramas para discriminação de ambientes tectônicos e em aranhogramas normalizados para granito de cadeias oceânicas, mostram características de granitóides pré- a sin-colisionais, sendo, então, considerados produtos magmáticos de ambientes tectônicos convergentes, representando, provavelmente, diferentes estágios e/ou diferentes arcos de ilha calcioalcalinos. A SCAK, nestes mesmos diagramas, mostra características de granitos sin-colisionais e, considerando-se também os dados de campo, é interpretada como produto da anatexia de rochas da crosta continental.

\section{Referência Bibliográfica}

CORDANI, U.G.; DELHAL, J.; LEDENT, D. (1973) Orogeneses superposées dans le précambrien du Brésil Sud-Oriental (Etats de Rio de Janeiro et Minas Gerais). Revista Brasileira de Geociências, v.3; p.1-22. 